\title{
Impact of Flash Flood on Agriculture Land in Tanguar Haor Basin
}

\author{
Md. Sahadat Hossain, Abdullah Al Nayeem ", Dr. Ahmad Kamruzzaman Majumder \\ Department of Environmental Science, Stamford University Bangladesh, Dhaka 1209, Bangladesh \\ *Corresponding Author: Abdullah Al Nayeem, Department of Environmental Science, Stamford \\ University, Bangladesh
}

\begin{abstract}
Tanguarhaor, the most diversified ecosystem is not only ecologically but also socio-economic important for supporting livelihood to around 70,000 people. Geographical location has made it vulnerable to adverse impacts by flash flood in almost every year. Our study aims to assess the loss of agricultural land cover due to flash flood occurred on April 2017. We have used 'before' and 'after' satellite images extracted from USGS database to assess the change of land cover in Tanguarhaor basin. Our result shows that a considerable area of agricultural land has been submerged by this flash flood and eventually a significant amount of crop has been lost. Consequently, almost 60 thousand people are at risk to suffer from food insecurity along with scarcity of safe drinking water due to contamination of pathogenic water microbes from unhygienic sanitary condition. Hence, we expect this study will help to visualize the loss of crop production that may play a significant role for ensuring food security in the haor basin of Bangladesh.
\end{abstract}

\section{INTRODUCTION}

Bangladesh have different types of freshwater wetlands including haor, baor, beels, stream, rivers, fresh water lakes, ponds etc. Almost 461 different kind of wetlands are available in Bangladesh whereas most of the largest and famous are Tanguar haor and Hakaluki haor(Chakraborty, 2005). Maximum freshwater wetlands in Bangladesh extend the low lying plain of eastern Mymensingh and Western Sylhet division. These wetland resources play a vital role to livelihood, economy and ecology of the country (Mwape, 2009). Wetlands are very important for life and livelihood and many people of Bangladesh are dependent on these natural resources. Those wetlands are the sources of fisheries, irrigation, biodiversity, breeding place, flood control system, navigation etc(Rahaman et al. 2016).

Different meteorological and hydrological phenomenon is the resulting of flooding which may extend to unexpected severity for losses of livelihood, ecological balances and infrastructure. In worldwide flood is a destructive natural hazards which damage the environment and human settlement. Haor flood lead to reduce the economic condition of farmer who are totally depend on the agriculture(Rahman, 2014). The farmer of haor area depend on those land where almost $80 \%$ area are covered by the boro rice production. In the haor area the practices of crop production techniques, livelihood condition, and socio economic condition are much different from other parts of the country. Recent year flood attack to the some of the haor area which destructed the agricultural land with huge amount of rice crop in north-east region of the country(Khan et al., 2012).

Tanguar haor encompasses two upazilas of Sunamganj district which are namely Tahirpur and Dharmapasha. Tanguar haor basin consists of almost 10,000 ha area of land and also supports to 60,000 population for their livelihood (Albertsen, 2012). It consists of diverse types of floral and faunal diversity especially reptiles, birds, fish species, amphibians etc. They play an important role to continue the haor ecosystem (Choudhury, 2016). However, unsustainable extraction and utilization of its natural resources cause to extensive threat to this haor ecosystem. Tanguar haor is declared as an "Ecologically Critical Area" by the Government of Bangladesh in 1999 for highlight to maintain the ecological system of this haor basin (CNRS, 2008).

Boro rice is the main crop of this basin area and most of the people depend on this rice production for their livelihood. Unfortunately pre monsoon flash flood comes with intensive devastation on rice 
production before harvesting ( Land, A.). The overflow of hilly rivers is to be the main cause of flash flood. Low lying areas of north eastern parts are mostly flood prone area. The Sunamganj district is located in the north eastern part of Bangladesh which encompasses around 95 haors(IFRC, 2010). Most of the people of this basin area are poor and agriculture is their main occupation. But the sudden flash flood cause to loss of crop production by submerging agricultural land which creates adverse impact on socio-economic life of the haor inhabitants. Moreover, it does not only hamper the normal life-style of human of this haor region but also the total aquatic ecosystem. Our study aims to assess the change in agricultural land at Tanguar Haor due to flash flood occurred in April 2017.

\section{STUdy AREA}

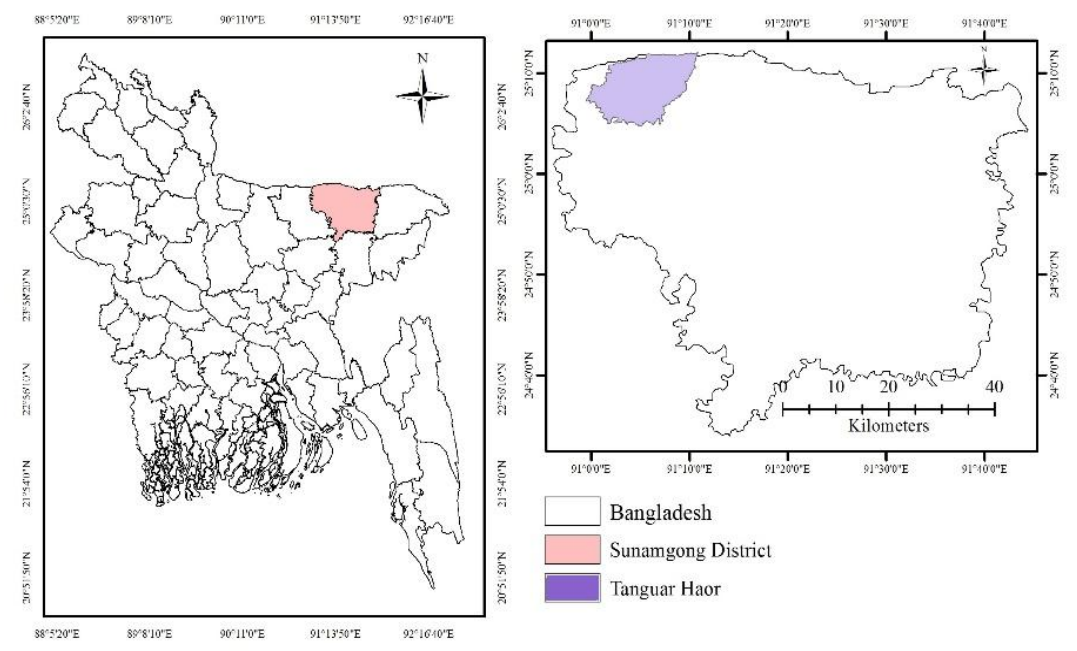

Figure 1. Map shows the Study Area

Tanguar haor is situated between the $25.1615^{\circ} \mathrm{N}$ and $91.0778^{\circ} \mathrm{E}$, lies in Dharmapasha and Tahirpur Upazila of Sunamganj district of Bangladesh with covering $100 \mathrm{~km}^{2}$ in which 2802.36 ha is wetland. Aside of, it contains 46 villages, 10 mauzas and around 120 Beel (Banglapedia 2014).

\section{Methodology}

The study has analysed the secondary data including relevant research articles, different qualitative and quantitative research reports to understand the historical changes in agricultural land in Tanguar haor. Besides, maps and satellite imagery are used for better understanding the change of Tanguar haor 'before' and 'after' flood. We used remote sensing technique for collecting the information regarding the land cover changes. Remote sensing technology provide effective image for the analysis and interpretation with low cost. Landsat imagery are much effective for mapping and measuring the change deduction of agriculture land and water body. The Landsat- 8 satellite image data has been downloaded from the United States Geological Survey (USGS) online database for 'before (2017/02/18)' and 'after' (2017/05/25) the flash flood in Tanguar haor, April 2017. The Operational Land Imager (OLI) acquired these scenes, which collect multispectral data (red, green, blue and nearinfrared bands). Afterward, maximum likelihood method has used by drawing 45 points for water area, 45 for agricultural land cover and 20 for bare soil in ArcGIS 10.2.1 and produced maps for both before and after flood for interactive visualization and representation of Tanguar haor area. Geographical Information System (GIS) is used for being a useful tool, has been using for scientific study impacts assessment and change detection. In addition, Microsoft Excel is used for calculating the change detection in percentages and tabulation.

\section{RESUltS AND DisCUSSION}

This study has classified Tanguar haor area for before and after flash flood into three major categories: water, agricultural land and bare soil. By using maximum likelihood method for classifying USGS satellite imagery, the study found a considerable change is land cover changes in Tanguar haor area (Figure 2 and Table 1). 
Table 1. Changes in land cover in Tanguar haor before and after the flash flood in April 2017

\begin{tabular}{|c|c|c|c|c|}
\hline Value & $\mathrm{Km}^{2}$ & Before $(\%)$ & $\operatorname{After}(\%)$ & Total Change \\
\hline Water Body & 67.77594 & 23.28 & 70.14332 & 46.87 \\
\hline Agriculture Land & 139.3621 & 47.86 & 14.22841 & -33.64 \\
\hline Bare Soil & 84.02778 & 28.86 & 15.62827 & -13.23 \\
\hline Total & 291.1658 & 100 & 100 & \\
\hline
\end{tabular}
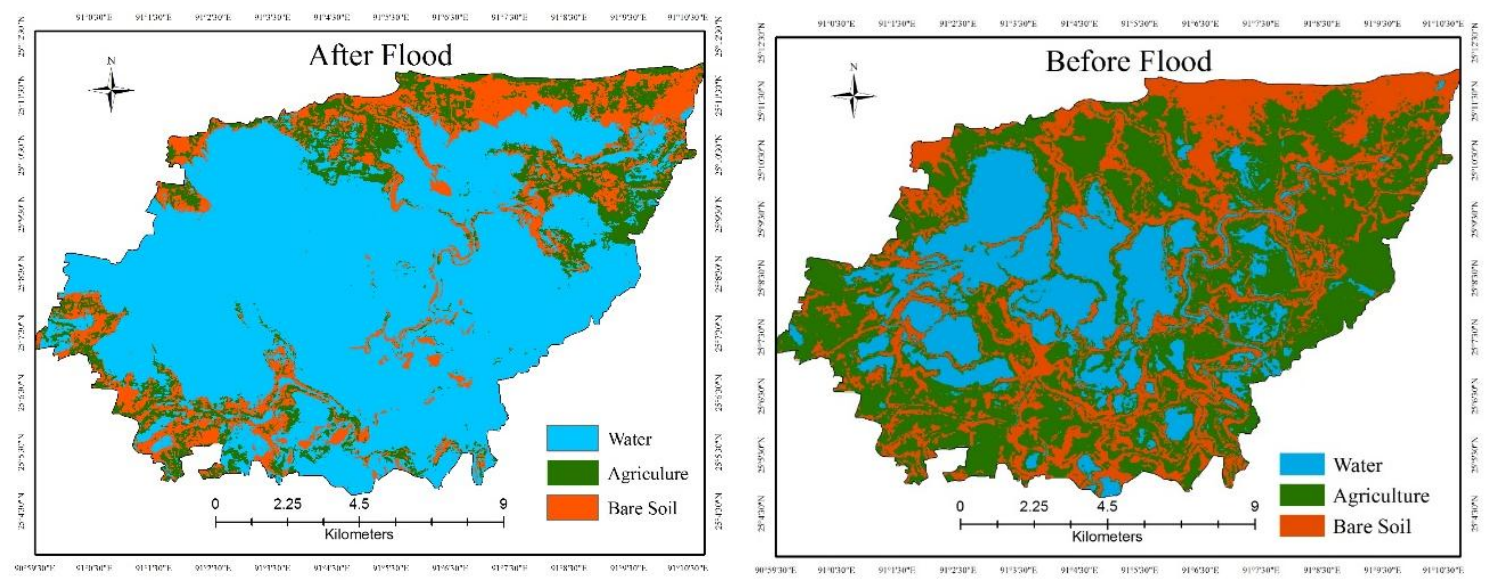

Figure 2. Map shows the Change deduction due to Flash Flood.

Tanguar haor is the $1031^{\text {st }}$ Ramsar site, which specifically popular for its rich biodiversity. It consists almost 137 species of fish and 284 species of birds. It also contains amphibians, mammals, reptiles etc (IUCN 2017). Like other haor and baor of Bangladesh, Tanguar haor remains at risk to flash flood in every monsoon season due to drainage of Meghalaya and Asam hilly areas of India during the rainfall. Flash flood occurred in April, 2017 is such an example that cause to inundate the boro agriculture land and lead to damage paddy land (Table 1) and endangered people to be food insecure (banglanews24.com). According to DAE there are about 18610 ha agricultural land in Dharmapasha and 7610 ha in Tahirpurupazila are submerged due to this flash flood.

Table 2. Crop damage due to flood in April 2017 (Source: Department of Agricultural Extension)

\begin{tabular}{|l|l|l|}
\hline Upzaila Name & $\begin{array}{l}\text { Total area under boro cultivation } \\
\text { (Ha.) }\end{array}$ & $\begin{array}{l}\text { Damage of standing crop in } \\
\text { Boro fields (Ha.) }\end{array}$ \\
\hline Dharmapasha & 31,800 & 18,610 \\
\hline Tahirpur & 18,400 & 7,610 \\
\hline
\end{tabular}

\section{CONCLUSION}

We found a considerable changes due to flash flood in haor basin, which destroy thousand hector of rice crop with agricultural land. Due to the flash flood occurred food crisis around the haor basin livelihood. The prices of al daily product increased, because of damaging crop land. Flood damage the rice production in the haor area and its lead to the negative impact on the food security and as well as the national economic condition. We have to reduce the flash flood in haor area for the overall condition of the country. The Availability of seeds, fertilizer, machinery instrument may be reduces some of the problem. And also the establishment of embankment, levee or dredging will help to control the flash flood(Khan et al., 2012). We used secondary data for this research work. We are going forward to do accuracy assessment of haor basin area on the basis of ground truth point. For more study and for effective result we will do a survey on the basis of people's perception, which will help us to identify the status of food security and crop damaging modelling during the flash flood season. By the help of this study we also going forward for future study on the total haor basin management of Bangladesh.

\section{REFERENCES}

Albertsen, J. O. (2012) Biodiversity of Tanguar Haor: A Ramsar Site of Bangladesh, Waterbirds.

Ali, Y. (2017) 'Bangladesh Haor devastating flood of April 2017-A Glaring example of Climate Change Effect', (April), pp. 1-5.

Backlund, P., Janetos, A. and Schimel, D. (2008) 'The Effects of Climate Change on Agriculture , Land Resources, Water Resources, and Biodiversity in the United States', Program, (May), p. 240. Available 
at: http://www.climatescience.gov.

CEGIS (2012) 'Master Plan of Haor Area', Ministry of Water Resources, I(April 2012).

Chakraborty, T. R. (2005) 'Management of Haors, Baors, and Beels in Bangladesh Lessons for Lake Basin Management'.

Châu, V. N. (2014) 'Assessing the Impacts of Extreme Floods on Agriculture in Vietnam : Quang Nam Case Study'.

Choudhury, M.-U.-I. (2016) 'Wetland-community resilience to flash flood hazards (Bonna) in Sunamganj district, Bangladesh'.

http://mspace.lib.umanitoba.ca/xmlui/handle/1993/30998.

Deshwara, M. (2017) 'Fish dying at Hakaluki haor after flood', pp. 7-9.

Hossain, M. D. (2013) 'Flood damage and risk assessment model in the haor basin of Bangladesh', (September).

Israel, D. C. and Briones, R. M. (2013) 'Impacts of Natural Disasters on Agriculture , Food Security, and Natural Resources and Environment in the Philippines October 2012', ERIA Discussion Paper Series, (October), pp. 1-53. doi: 10.1007/s10273-011-1262-2.

Khan, M. N. H., Mia, M. Y., \& Hossain, M. R. (2012). Impacts of Flood on Crop Production in Haor Areas of Two Upazillas in Kishoregonj. J. Environ. Sci. \& Natural Resources, 5(1), 193-198. https://doi.org/10.3329/jesnr.v5i1.11581

Rahman, S. U. (2014). Impacts Of Flood on The Lives And Livelihoods of People in Bangladesh: A Case Study of a Village in Manikganj District, BRAC University, Dhaka, Bangladesh.

John A. Wilson 'Farming after the Flood'.

Land, A. 'Farms and Agricultural Land Flooding of farms and agricultural land', pp. 1-2.

Might, Y. and Like, A. (2017) 'Latest from National BAU expert team in Tanguar Haor', pp. 11-13.

Mwape, Y. P. (2009) 'An Impact of Floods on the Socio-Economic Livelihoods of People: a Case Study of Sikaunzwe Community in Kazungula District of Zambia', Disaster Risk Management Training and Education Centre for Africa (DiMTEC).

Nirapad (2017) 'Flash Flood Situation Update, May 03, 2017', Flash Flood Situation Update.

Profile, C. and Profile, P. (2014) 'PRE-DISASTER SECONDARY DATA', 80(March), pp. 1-20.

Rahaman, M. M., Sajib, K. I. and Alam, I. (2016) 'Impacts of Climate Change on the Livelihoods of The People in Tanguar Haor, Bangladesh', Journal of Water Resource Engineering and Management, 3(1), pp. $1-9$.

Read, M. (2017) 'due to ash ood', pp. 11-12.

CNRS Report. (2008) 'Adopting Early Warning System To Address Flash Flood in the Deeply Flooded Haor Basin in Tahirpur of Sunamganj District To Address Flash Flood in the Deeply Flooded Haor Basin in Tahirpur', (December).

Salam, U. (2017) 'Prelude to a spreading nightmare', pp. 1-6.

Sharma, P. K. (2010) 'Scenario of haor vulnerabilities and other obstacles for sustainable livelihood development in Nikli Upazila', Journal of the Bangladesh Agricultural University, 8(2), pp. $283-290$. Available at: http://www.banglajol.info/index.php/JBAU/article/viewFile/7939/5893.

Sidi, M. S. (2012) 'The Impact of The 2012 Floods on Agriculture And Food Security In Nigeria Using GIS ', (November), pp. 7-9.

'Flash Flood Situation, April 19, 2017'.

IFRC, (2010) 'Bangladesh : Flash Flood'.

Strategy, P. (2015) 'Haor Region', pp. 2015-2020.

Suman, A., Akther, F. and Bhattacharya, B. (2014) 'Climate Change Impact on Haor flooding in Bangladesh using Three Global Circulation Models', 1174(3), pp. 1170-1174.

Wagner, K., Neuwirth, J. and Janetschek, H. (2009) 'Flood risk - Prevention and Impact on Agricultural Lands', Agricultural Economics, (April), pp. 1-7.

http://en.banglapedia.org/index.php?title=Tanguar_Haor

Citation: Md. S. Hossain et al., " Impact of Flash Flood on Agriculture Land in Tanguar Haor Basin ", International Journal of Research in Environmental Science, vol. 3, no. 4, p. 42-45, 2017. http://dx.doi.org/10.20431/2454-9444.0304007

Copyright: (C) 2017 Authors. This is an open-access article distributed under the terms of the Creative Commons Attribution License, which permits unrestricted use, distribution, and reproduction in any medium, provided the original author and source are credited. 